\title{
CAREER INDECISION
}

\begin{abstract}
In this paper career indecision as a complex and multidimensional construct that attracts considerable research interest in the field of vocational psychology is presented. The introductory part describes this construct through one of the most commonly used definitions and the negative outcomes it can cause. The second part explains how the career indecision is integrated into the vocational theories/theories of career choice and development, followed by an overview of the empirical findings on its structure and causes of cognitive and emotional nature. The distinction between career indecision and indecisiveness, as well as the difference between developmental, chronic and acute career indecision are explained in the last part. In the conclusion part the importance of the career indecision for vocational guidance and career counselling is emphasized.
\end{abstract}

Keywords: CAREER INDECISION, CAREER CHOICE, STRUCTURE

Since career choices are one of the most important decisions in one's life, it is understandable that the career decision-making process plays a significant role in vocational psychology. Osipow et al., (1980, as cited in Gati \& Asher, 2001) pointed out that making a career choice as a very complex and important task involves undecidedness, and often leads to feelings of discomfort, anxiety, and confusion. Thus, some people make decisions very easily without obvious difficulty, while for others career decision-making can be a challenging process (Gati, Krausz, \& Osipow, 1996; Lipshits-Braziler, Gati, \& Tatar, 2017).

To describe these difficulties the term career indecision is used in the literature. Namely, this construct is most broadly defined as the difficulties faced by an individual when she/he needs to make career related decisions (Chartrand, Rose, Elliot, Marmarosh, \& Caldwell, 1993; Gati et. al., 1996; Leong \& Chervinko, 1996, as cited in Hijazi, Tatar \& Gati, 2004; Osipow, Carney \& Barak, 1976, as cited in Saka, Gati \& Kelly, 2008), resulting in inability to make a final choice (Slaney, 1988). It refers to any problem or barrier (Fuqua, Blum, \& Hartman, 1988) that may arise before, during, or after the decision-making process (Amir \& Gati, 2006; Saka et al., 2008).

Given that many career choices should be made throughout one's lifespan - such as educational choice, occupational choice, choice of training/ course or employment, indecision can occur in each of these situations by imposing a delay in decision-making or leading to uncertainty. In addition, career indeci- 
sion may be accompanied by anxiety and lack of motivation to overcome difficulties that can lead to career development problems, especially in the adolescence (Kelly \& Lee, 2002) when young people are faced with significant developmental challenges (Škarić, 2009). In fact, the career indecision among adolescents has been extensively researched, but on the other hand, empirical findings on this construct are lacking among adults/employees ( $\mathrm{Xu}, 2020)$.

\section{Career indecision in the vocational theories}

Despite the empirical findings of career indecision, particularly in the adolescence, as well as the acknowledgement on its importance, it can be concluded that this construct is not sufficiently integrated in the existing vocationnal theories (theories of career choice and development). Savickas (2005) considered career indecision as one of the structural elements of the career adaptability - the central construct in his theory of career choice and development. Career adaptability refers to an individual's readiness and potential for coping with current and anticipated vocational tasks and has four dimensions: career concern, career control, career curiosity, and career confidence. One end of the dimension career control is the belief of the individual that he/she is responsible for his/her career, while indecision is on the opposite end, referring to lack of control or inability to make career decisions, and go along with confusion, procrastination, or impulsivity (Savickas, 2013). According to the author, dysfunctional career beliefs lead to decision-making difficulties such as indecision (Savickas, 2002), and as he points out, it can be overcome by strengthening decision-making skills and abilities, which in turn can foster readiness for career exploration. (Savickas, 2005). This, in fact, represents new approach to the concept of vocational maturity in Super's theory of career choice and development.

Career readiness, according to Super (Super, 1953, 1990, as cited in Leong \& Serafica, 2001), underlies vocational maturity and denotes an individual's ability to cope with vocational tasks at different stages during the lifespan. It is expressed through attitudes towards career choice and through competencies to make decisions. Attitudes refer to the efforts and plans a person makes for future educational or occupational choices. They reflect the awareness that choices need to be made and emphasize career exploration based on curiosity about work and work roles. Competencies as ability of an individual to apply career and world of work related knowledge in the career decisionmaking process include information about occupations and benefits they provide, as well as skills to apply rational decision-making principles (Super, 1974, as cited in Glavin, 2006).

In the cognitive information processing approach to career problem solving and decision- making, career indecision is the initial state the individuals are faced when they need to make a career-related decisions, while the problem-solving process represents overcoming the state of indecision and achieving a state of decidedness (Peterson, Sampson, Lenz, \& Reardon, 2002). The authors describe the career indecision in terms of the unwillingness of the in- 
dividual to get engaged in the career decision-making process. They have stated that dysfunctional career decision-making thoughts manifested through confusion, anxiety, and external conflicts, are cause of aforementioned condition. The opposite state of the career indecision is readiness defined as the ability of the individual to make career choices taking into account the complexity of the family, economic, and organizational factors. Ability refers to internal factors (cognitive and affective), while complexity encompasses external factors that can influence career decision-making process (Sampson et al.,2000a, as cited in Peterson et al., 2002). Individuals with highly expressed readiness are characterized by cognitive abilities and positive affect,that lead to effective career problem solving. In contrast, low readiness is accompanied by negative thoughts and negative affect causing career decision making difficulties.

Problems and barriers in the career decision-making process are discussed in other vocational theories, as well. Gottfredson (2002), for example, agreed that various barriers may impede career decision-making such as: limited educational and employment opportunities, discrimination in the labour market, the absence of occupations that include a combination of preferred sex type, prestige and interests. In Holland's theory, inconsistency between the interests that form the individual's vocational type is perceived as a career related barrier. For example, enterprising and investigative interests do not have common characteristics and if together represent a person's code of interests/ vocational personality, it is very likely, to be experienced as a difficulty in the career decision-making process (Spokane, Luchetta, \& Richwine, 2002). In the same line, cause of career decision -making difficulties might be the lack of congruence between individual's interest code/vocational personality type and the type of work environment.

\section{Structure of the career indecision}

Notwithstanding the lack of integration into vocational theories, there are empirical findings on career indecision implying to its complexity and multidimensional nature. In several studies (using the Career Decision Scale instrument) following dimensions of career indecision have been identified - diffusion, support, approach -approach and external barriers (Schimizu et al., 1988; Vondracek et al., 1990, as cited in Schimizu, Vondracek \& Schulenberg, 1994). On the other hand, there are authors who stated that career indecision is a onedimensional construct (Martin, et al., 1991, as cited in Guay, Ratelle, Senécal, Larose, \& Deschênes, 2006). Kelly \& Lee (2002) identified six factors that represent the structure of the career indecision measured by the Career Decision Scale, Career Factor Inventory and Career Decision Making Difficulties Questionnaire - lack of information, need for information, indecision, disagreement with others, identity diffusion and anxiety.

After the factor analysis of 24 correlation matrices, Brown \& Rector (Brown \& Rector, 2008) reported on a four-factor structure of the career indecision. The first factor refers to chronic indecision and is defined by high lev- 
els of anxiety, depressed mood, low self-esteem, low confidence in own decision-making skills, tendency of avoidance instead of approaching the problem, dependence on others' opinions and focus of negative outcomes in career decision-making process. The second factor represents the lack of information dimension, while the third reflects external barriers and interpersonal conflicts. The latter factor named as identity diffusion includes lack of confidence in career decision-making skills, unclear career attitudes, unstable career goals, lack of motivation to make career choices and / or to persist in own decisions, low conscientiousness.

Another study (Brown \& Crane, 2000, as cited in Hammond, Lockman \& Boling, 2010) proposed a tripartite model of career indecision that contained three first-order factors: negative affect, underdeveloped vocational identity, and need for career-related information. They are represented by seven second order factors: negative affect (refers to the first higher order factor), vocational identity, career maturity, goal setting, self-efficacy, problem solving (consisted the second higher factor) and the need for information about career (part of the third higher order factor). Hammond et al. (2010) added emotional intelligence and positive affect to the above variables in order to obtain a more complete model of the career indecision sources. Factor analysis revealed five-dimensional model defined by the following factors career self-efficacy, career-related emotional maturity, need for information, vocational identity development and career decision status (degree of decidedness, satisfaction/pleasure in decision making and the choice importance).

Based on the rational decision theory and decision-making model of Pitz and Haren, three sources of indecision have been identified by Germeijs \& De Boeck (2003). One source is the lack of information denoted to insufficient information about the occupations/alternatives and/or their characteristics, as well as lack of information about the outcomes of that alternatives.

Gati, Krautz, and Osipow (1996) using existing decision-making and information processing theories, on the one hand, as well as empirical research on the characteristics, dimensions, and sources of the career indecision (e.g. Kleiman et al., 2004), on the other hand, developed a taxonomy of the career decision-making difficulties. It is based on the following propositions:

$\checkmark$ when the person is aware that she/he should make a decision, is willing to engage in that process, and has skills to make decision that fits her/his goals, than the career decision-making process is ideal;

$\checkmark$ in other case, there are difficulties that may delay the occupational/ career choice;

Difficulties can be classified into several categories depending on:

a) the time when they occur (prior or during the engagement in the career decision-making process),

b) the source of the difficulty (affective or cognitive), 
c) the impact of the difficulty on the decision-making process (blocking the process or leading to incomplete/unsatisfactory decision),

d) the type of intervention required to overcome the difficulty;

$\checkmark$ indecision can arise from one difficulty or be a combination of several difficulties;

$\checkmark$ difficulties may belong to one or several categories.

The proposed taxonomy includes three levels of categorization of the difficulties in the career decision-making process. At the first level, they are divided into two groups according to whether they occur before or during the career decision making process. At the next level the difficulties are differentiated within the two groups. Difficulties named as lack of readiness to be engaged in the decision-making process contained the first group, while the second group distinguished between lack of information and inconsistent information related to career decision-making process. At the last, third, level of categorization these three general categories are divided into specific subcategories. As the authors pointed out, the categorization is based on several criteria: the difficulties to be located at the same stage in the decision-making process, to arise from the same source, to have similar consequences on the efficiency of decision-making and to imply to similar interventions that should be used to overcome them. The dimension lack of readiness is consisted of the following subdimensions: 1) lack of motivation, 2) generalized indecisiveness and 3) dysfunctional beliefs. The lack of information dimension is divided into these sub-dimensions: 1) lack of information about the decision-making process, 2) lack of information about oneself, 3) lack of information about occupations and 4) lack of information about ways of obtaining information. The sub-dimensions that are part of the inconsistent information dimension are: 1) unreliable information, 2) internal conflicts and 3) external conflicts.

The authors have constructed an instrument (Career Decision Making Difficulties Questionnaire) to measure difficulties in the career decision-making process. A very recent extensive study (Levin, Braunstein, Lipshits-Braziler, Gati, \& Rossier, 2020) confirmed the internal structure of this instrument, its reliability and scalar invariance in seven English-speaking countries. Similar findings regarding the proposed structure and reliability were found in other studies conducted among high school students (e.g. Babarović \& Šverko, 2019, Baçanli, 2016), including a study conducted on a sample of Macedonian high school students (Blaževska-Stoilkovska \& Kenig, 2015).

In addition to the described taxonomy that addresses the cognitive aspects of the career indecision, a model of emotional and personality characteristics as its sources has been developed recently. Three basic dimensions of this model are: 1) pessimism, 2) anxiety and self-concept and 3) identity (Gati et al., 2011; Saka et al., 2008; Saka \& Gati, 2007). Pessimism refers to the decision-making process itself, to the work, and to the personal control over events; anxiety is related to the decision-making process, uncertainty, career choice, as 
well as to the outcomes of the decision-making; identity is associated with general anxiety, self-esteem, undifferentiated values, preferences and goals, and attachment and separation problems with important others (Saka et al., 2008).

As a result of the literature review on career indecision, a recent study proposed an integrative five-dimensional model of the career indecision - neuroticism, need for information, lack of readiness, and interpersonal conflicts (Xu \& Bhang, 2019).

\section{Types of indecision in choosing a career}

Considering research on career indecision, as well as its practical implications (in vocational guidance and broadly in career counselling), it is very important the distinction between career indecision and trait indecisiveness to be clearly emphasized. While indecisiveness refers to difficulties in decision making in general/in any situation (Germeijs \& De Boeck, 2002), career indecision reflects career decision problems. In order to better understand this difference it is pointed out that individuals with generalized indecisiveness have difficulties in making life decisions whether those decisions are of high or low importance, while individuals with career indecision cannot make vocational choices even when they have freedom to do so, when they have support and encouragement (Crites, 1969, according to Germeijs \& De Boeck, 2002).

Furthermore, there are temporary, developmental indecision, chronic or pervasive indecision and acute, i.e. situational indecision (Fuqua \& Hartman, 1983). Developmental indecision is a focal problem related to specific career goals (Kelly \& Schin, 2009), understood as a developmental task that can be overcome as students get/acquire more information about themselves and about occupations (Guay et al., Ratelle, Senécal, Larose \& Deschénes, 2006). In contrast, chronic indecision continues to persist permanently despite academic and work experience (Kelly \& Shin, 2009) and is accompanied by psychological dysfunction and needs long-term treatment (Hartman, Fuqua, \& Hartman, 1983). According to Saka et al. (2008), this type of career indecision is a consequence of personality traits and / or certain emotional factors. Walsh (2004) emphasizes the consistency of the findings revealing that dimension of neuroticism is highly expressed among people who manifest chronic indecision. Salomone (as cited in Brown \& Rector, 2008) has suggested that chronically indecisive people are characterized by feelings of hopelessness, dependence, immaturity, anxiety, and low levels of self-confidence and self-esteem.

Acute situational indecision, on the other hand, is due to external stressors, such as institutional rules that require the individual to make a final decision within a certain time frame that can be experienced as a pressure (Faqua \& Hartman, 1983). Guy et al. (2006) stressed that high school students at risk of becoming chronically indecisive are those who have low support for autonomy from important others (parents and peers) and a low degree of perceived autonomy and self-efficacy. They suggested that the degree of career indecision 
should be measured over a long period of time in order to distinguish between individuals with developmental and chronic indecision. Their findings showed that over time, if indecision decreases, then it is a temporary condition, but if it remains at the same level, then it is chronic.

\section{Conclusion}

Career indecision can be a transient part of the adolescence. On the other hand, it can be manifested as a chronic state of indecision. Levin et al. (2020) reported that cognitive sources of career indecision decreases from adolescence to adulthood, while emotional personality causes increases from adolescence to young adulthood which might be a partial support for the distinction between career indecision and indecisiveness.

Given that career choices can have long-term implications on subjective well-being, socioeconomic status, as well as on lifestyle and a sense of personal contribution to the society (Gati \& Tal, 2008) and are very important for mental health in general (Foad \& Bynner, 2008), then the knowledge of the career indecision and its causes are very important. Adequate assessment of the career indecision can contribute to the effectiveness of the counselling in this domain (Gati \& Levin, 2014), but also could be a basis, especially for the young people, to seek support and guidance in the vocational/career decision-making process. An additional but equally important reason career indecision to be taken into consideration is the increasing frequency of career transitions nowadays (Kulscár, Dobrean, \& Gati, 2020).

\section{References:}

AMIR, T., \& GATI, I. (2006). Facets of career decision-making difficulties. British Journal of Guidance \& Counselling, 34, 483 - 503.

BABAROVIĆ, T., \& ŠVERKO, I. (2019). The Validity of Career Decision-Making Difficulties Questionnaire in Croatia. Journal of Career Assessment , 27 (3), 391-407.

BAÇANLI, F. (2016). Career decision-making difficulties of Turkish adolescents. International Journal of Educational and Vocational Guidance , 16, 233-250.

БЛАЖЕВСКА СТОИЯКОВСКА, Б., И КЕНИГ, Н. (2015). Испитување на психометриските карактеристики на Прашалникот за мерење на неодлучноста при изборот на кариера. Психологија: наука и практика, 1 (2), $27-41$.

Brown, S. D., \& ReCtoR, C. C. (2008). Conceptualizing and Diagnosing Problems in Vocational Decision Making. In Brown, S. D. \& Lent, R. W. (Eds.), Handbook of Counseling Psychology (4th ed., pp. 392-407). John Wiley \& Sons, Inc. 
Chartrand, J. M., Rose M. L., Elliot, T. R., Marmarosh, C., \& Calldwell, S. (1993). Peeling Back the Onion: Personality, Problem Solving and Career Decision Style Correlates of Career Indecision. Journal of Career Assessment, 1 (1), 66-82.

FouAD, N. A., \& BYNNER, J. (2008). Work transitions. American Psychologist, 63(4), 241-251. https://doi.org/10.1037/0003-066X.63.4.241.

FuguA, D. R., BluM, C. R., \& HARTMAN, B.W. (1988). Empirical support of the Differential Diagnosis of Career Indecision.Career Development Quarterly, 36, 364-373.

FUQUA, D. R., \& HARTMAN, B. W. (1983). Differential diagnosis and treatment of career indecision. Personnel \& Guidance Journal, 62(1), 27- 29. https://doi.org/10.1111/j.2164-4918.1983.tb00112.x

GATI, I., \& Asher, I. (2001). Prescreening, In-Depth Exploration, and Choice: From Decision Theory to Career Counseling Practice. Journal of Career Development Quarterly, 50 (2), 140-157.

GATI, I., GADASSI, R., SAKA, N., HADAdi, Y., ANSENBERG, N., Friedman, R., \& AsULIN-PERETZ, L. (2011). Emotional and Personality Related Aspects of Career Decision-Making Difficilties: Facets of Career Indecision. Journal of Career Assessment, 19 (1), 3-20.

GATI, I., \& LEVIN, N. (2014). Counseling for career decision-making difficulties: Measures and methods. The Career Development Quarterly, 62(2), 98113. https://doi.org/10.1002/j.2161-0045.2014.00073.x

GATI, I., KRAUTZ, M., \& OsIPOW, S. H. (1996).A Taxonomy of Difficulties in Career Decision-Making. Journal of Counseling Psychology, 43 (4), 510-526.

Gati I., \& TAL S. (2008) Decision-Making Models and Career Guidance. In: J.A. Athanasou \& R. Van Esbroeck (Eds.) International Handbook of Career Guidance (pp. 157-185). Springer.

GERMEIJS, V., \& DE BOECK, P. (2003). Career indecision: Three factors from decision theory. Journal of Vocational Behavior, 62, 11-25.

GermeIJS, V., \& De BOeCK, P. (2002). A Measurement Scale for Indecisiveness and Its Relationship to Career Indecision and Other Types of Indecision. European Journal of Psychological Assessment, 18 (2), 113-122.

GLAVIN, K. W. (2006). Career choice readiness. In Greenhouse, J. H. \& Callanan, G. A. (Eds.), Encyclopedia of Career Development (pp. 98-99). Sage Publications, Inc.

GotTFREDSON, L. S. (2002). Gottfredson's Theory of Circumscription, Compromise and Self-Creation.In D. Brown and Associates (Eds), Career Choice and Development (4th ed) (pp. 85-148). Jossey-Bass.

Guay, F., Ratelle, C. F., SenéCal, C., Larose S., \& DeschêNes, A. (2006). Distinguishing Developmental From Chronic Career Indecision: Self-Efficacy, Authonomy, and Social Support. Journal of Career Assessment, 14 (2), 235-251. 
HAMOND, M. S., LOCKMAN, J. D., \& BOlING, T. (2010). A Test of Tripartite Model of Career Indecision of Borwn and Krane for African Americans Incorporating Emotional Intelligence and Positive Affect.Journal of Career Assessment, 18 (2), 161-176.

HARTMAN, B.W., FuQUA, D.R., \& HARTMAN, P.T. (1983). The Predictive Potential of the Career Decision Scale in Identifying Chronic Career Indecision. Vocational Guidance Quarterly, 32(2), 103-108. https://doi.org/10.1002/j.2164-585X.1983.tb01564.x

Hijazi, Y., TAtaR, M., \& GATI, I. (2004). Career Decision-Making Difficulties Among Israeli and Palestinian Arab High-School Seniors. Proffesional School Counseling, 8, 64-72.

KELLY, K. R., \& LEE, W. C. (2002). Mapping the domain of career decision problems. Journal of Vocational Behavior, 61, 302-326.

KELLY, K. R., \& SCHIN, Y. L. (2009). Relation of Neuroticism and Negative Career Thouhgts and Feelings to Lack of Information.Journal of Career Assessment, 17 (2), 201-213.

Kleiman, T., Gati, I., Peterson, G., Sampson, J., Reardon, R., \& LenZ, J. (2004). Dysfunctional Thinking and Difficulties in Career Decision Making. Journal of Career Assessment, 12 (3), 312-331.

KulCSÁR, V., DOBREAN, A., \& GATI, I. (2020). Challenges and difficulties in career decision making: Their causes, and their effects on the process and the decision. Journal of Vocational Behavior, 116(Part A), Article 103346. https://doi.org/10.1016/j.jvb.2019.103346.

LeONG, F. T. L., \& SERAFICA, L. W. (2001). Cross-Culture Perspective on Super's Career Development Theory: Career Maturity and Cultural Accommodation. In Leong, F. T. L. \& Barak, A. (Eds).Contemporary Models in Vocational Psychology: A Volume in Honor of Samuel H. Osipow (pp. 167-207). LEA Publishers.

LEVIN, N., BRAunstein, H., LiPSHITS-BRAZILER, Y., GATI, I., \& ROSSIER, J. (2020). Testing the Structure of the Career Decision making Difficulties Questionnaire across country, gender, age, and decision status. Journal of Vocational Behavior, 116, 1-13.

LIPSHITS-BRAZILER, Y., GATI, I., \& TATAR, M. (2017). Strategies for Coping with Career Indecision: Convergent, Divergent, and Incremental Validity. Journal of Career Assessment, 25(2), 183-202.

Peterson, G. W., SAmpson JR, J. S., LenZ, J. G., \& Reardon, R. C. (2002). A Cognitive Information Processing Approach to Career Problem Solving and Decision Making. . In D. Brown and Associates (Eds), Career Choice and Development (4th ed., pp. 312-369). Jossey-Bass.

SAKA, N., \& GATI, I. (2007). Emotional and Personality Related Aspects of Persistent Career Decision-Making Difficulties. Journal of Vocational Behavior, 71 (3), 340-358. 
SAKA, N., GATI, I., \& KeLLy, K. R. (2008).Emotional and Personality-Related Aspects of Career-Decision-Making Difficulties.Journal of Career Assessment, 16 (4), 403-424.

SAVICKAS, M. (2013). Career Construction Theory and Practice. In S.D. Brown \& R.W. Lent (Eds.) Career Development and Counseling: Putting Theory and Research to Work (2 ${ }^{\text {nd }} e d$.) (pp. 147-183). John Wiley \& Sons, Inc.

SAVICKAS, M. L. (2005). The Theory and Practice of Career Construction. In S. D. Brown and R. W. Lent (Eds), Career Development and Counseling: Putting Theory and Research to Work (pp.42-70). John Wiley \& Sons, Inc.

SAVICKAS, M. L. (2002). Career Construction: A Developmental Theory of Vocational Behavior. In D. Brown and Associates (Eds), Career Choice and Development (4th ed., pp. 179-205). Jossey-Bass.

SCHIMIZU, K, VONDRACEK, F. W.. \& SCHULENBERG, J. (1994). Unidimensionality Versus Multidimensionality of the Career Decision Scale: A Critique of Martin, Sabourin, Laplante \& Coallier. Journal of Career Assessment, 2 (1), $1-14$.

SLANEY, R. B. (1988). The assessment of career decision making. In W. B. Walsh \& S. H. Osipow (Eds), Contemporary topics in vocational psychology. Career decision making (pp. 33-76). Lawrence Erlbaum Associates, Inc.

SPOKANE, A. R., LuCheTtA, E. J., \& RichWine, M. H. (2002). Holland's Theory of Personalities in Work Environment. . In D. Brown and Associates (Eds), Career Choice and Development (4th ed., pp. 373-426). Jossey-Bass.

ШКАРИЌ, О. (2009). Психологија на детството и на адолесценцијата. Филозофски факултет - Скопје.

XU, H. (2020). Career Indecision Profile-Short: Reliability and Validity Among Employees and Measurement Invariance Across Students and Employees. Journal of Career Assessment, 28 (1), 91-108.

WALSH, B. W. (2004). Vocational Psychology and Personality. In Schneider, B. \& Smith, D. B. (Eds.), Personality and Organizations (pp. 141-162). LEA Publishers.

XU, H. \& BHANG, C. H. (2019). The Structure and Measurement of Career Indecision: A Critical Review. Career Development Quarterly, 67(1), 1-20. 